Biological and Applied Sciences

Vol.60: e17160539, January-December 2017 http://dx.doi.org/10.1590/1678-4324-2017160539 ISSN 1678-4324 Online Edition

\title{
Isolation, Characterization, Antioxidant, Antimicrobial and Cytotoxic Effect of Marine Actinomycete, Streptomyces Carpaticus MK-01, against Fish Pathogens
}

\author{
Dharaneedharan Subramanian $^{1}$, Min-Sun Kim ${ }^{1}$, Dong-Hwi Kim ${ }^{1}$, Moon-Soo Heo ${ }^{1 *}$. \\ ${ }^{1}$ Jeju National University - Marine Life Sciences Department, Jeju-Si, Korea.
}

\begin{abstract}
Present study aim to evaluate the antimicrobial, antioxidant and cytotoxic potential of crude extract of Marine Streptomyces carpaticus MK-01 isolated from seawater collected from Daejeong-cost of Jeju Island. About 24 actinomycetes strains were isolated and subjected to morphological and molecular analysis that confirmed the isolate as $\mathrm{S}$. carpaticus MK-01. Crude ethyl acetate extract of MK-01 strain showed extensive antibacterial activity against Gram-positive fish pathogenic bacteria namely Streptococcus iniae and S. parauberis with a maximum zone of inhibition $(0.92 \pm 0.03 \mathrm{~mm})$ was recorded against $S$. parauberis at the minimum extract concentration $(3.12 \mu \mathrm{g} / \mathrm{ml})$. The MK-01 ethyl acetate extract shows dose dependant significant increase in antioxidant activity. The 50\% cytotoxic concentration $\left(C C_{50}\right)$ of $M K-01$ ethyl acetate extract was attained at $53.71 \mu \mathrm{g} / \mathrm{ml}$ and the effective concentration $50\left(E C_{50}\right)$ against virus-infected Epithelioma papulosum cyprini cell lines was $8.72 \mu \mathrm{g} / \mathrm{ml}$ of $\mathrm{S}$. carpaticus $\mathrm{MK}-01$ crude ethyl acetate extract.
\end{abstract}

Key words: Actinomycete, Streptomyces carpaticus MK-01, antioxidant, cytotoxicity, Jeju Island

*Author for correspondence: msheo@jejunu.ac.kr. 


\section{INTRODUCTION}

Aquaculture is the fastest growing food-producing sector in the world, with an average annual growth rate of $8.9 \%$ from various agro-climatic zones ranging from tropical to temperate area ${ }^{1}$ which includes farmed fish, molluscs, crustaceans and aquatic plants. The world aquaculture has grown tremendously during the last fifty years from a production of less than a million tonnes to 59.4 million tonnes. Its production depends mainly on the impact of disease management in farmed fish species. In recent years, use of natural antibiotics, immunostimulants, pre- and probiotics to prevent and/or control pathogenic microbes has been increased ${ }^{2,3,4}$.

The discovery and development of antibiotics to treat life-threatening infections by bacteria is perhaps one of the greatest accomplishments of the mid twentieth century 5,6. The marine microorganisms especially bacteria and actinomycetes are virtually unlimited sources of novel compounds with many therapeutic applications. Among the above, actinomycetes are the most economically and biotechnologically priceless prokaryotes; hold a prominent position due to their diversity and proven ability to produce novel bioactive compounds ${ }^{7}$. As marine environmental conditions are extremely different from terrestrial ones, it is summarized that marine Actinomycetes have different characteristics from those of terrestrial counterparts and therefore might produce different types of bioactive compounds ${ }^{8}$. About 23,000 microbial bioactive compounds have been reported of which more than 10,000 compounds are produced by actinomycetes representing $45 \%$ of total microbial metabolites discovered ${ }^{9}$. Among those actinomycetes, $76 \%$ of bioactive compounds are from Streotomyces species which are noted as a primary antibiotic-producing organisms explored by the pharmaceutical industry ${ }^{10}$. Moreover, these species are efficient in the production of new secondary metabolites with wide range of biological activities including antifungal, anticancer, antitumor, cytotoxic, cytostatic, anti-inflammatory, anti-parasitic, anti-malaria, antiviral, antioxidant, antiangiogenesis, etc $^{11}$.

Hence, the present study was made to isolate actinomycetes - Streptomyces sps from seawater collected from Jeju Island and to assess its antioxidant, cytotoxicity and antimicrobial activity against major fish pathogens.

\section{MATERIALS AND METHODS}

Isolation and characterization of actinomycetes strains. The actinomycetes used in this study was isolated from seawater collected at approximately $0.5 \mathrm{~m}$ depth in sterile polypropylene bottles, from Daejeong-cost of Jeju Island. About $0.1 \mathrm{ml}$ of serially diluted $\left(10^{-1}\right.$ to $\left.10^{-5}\right)$ seawater samples with $0.85 \%$ physiological saline were spread over actinomycetes isolation agar ${ }^{12}$ and incubated at $28^{\circ} \mathrm{C}$ for $10 \pm 4$ days. After incubation period, the plates were examined for actinomycetes colony. The actinobacterial colonies were identified according to their morphological characteristics (scanning electron microscopy, JSM-6700F, JEOL Ltd., Japan; and Gram stain), then purified and stored at $-20^{\circ} \mathrm{C}$ as glycerol stock $(20 \%, \mathrm{v} / \mathrm{v})$. Among 24 isolates showing different morphological characteristics an isolate named MK-01 was chosen for the present study.

Characterization of the isolate $M K-01$. The isolate MK-01 was tested for its ability to grow at different $\mathrm{pH}(2,3,5,6,7,8,9,10,11$ and 12) and temperatures $(20,25$, $30,35,37,40,45^{\circ} \mathrm{C}$ ) on ISP2 medium ${ }^{13}$ incubated for $7 \pm 3$ days. Bacterial growth was assessed by measuring its absorbance at $610 \mathrm{~nm}$. For phylogenetic characterization isolate MK-01 was grown for 4 days at $30^{\circ} \mathrm{C}$ with agitations in $10 \mathrm{ml}$

Braz. Arch. Biol. Technol. v.60: e170539, Jan/Dec 2017 
Marine actinomycetes against fish pathogens

of ISP2 medium. The genomic DNA was isolated using genomic DNA islation kit (Bioneer, USA). The 16S rDNA gene of the isolate MK-02 was PCR amplified using bacterial universal primers $27 \mathrm{~F}$ (5'-AGAGTTTGATCCTGGCTCAG-3') and 1492 R (5'-GGTTACCTTGTTACGACTT-3') $)^{14}$. PCR amplified product was gel purified, cloned and sequenced. The obtained sequences were subjected BLASTN search and phylogenetic analysis was done using MEGA.5.1 software.

Extraction of bioactive metabolites. Isolated actinomycete colonies were inoculated to $500 \mathrm{ml}$ Marine broth and incubated for $10-15$ days at $28^{\circ} \mathrm{C}$ in shaker $(200-250$ rpm). After 15 days, the culture was taken and centrifuged at 3000-5000 rpm for 10 minutes. After centrifugation, the cell free supernatant was collected and filtered with Whatmann no.1 filter paper. To the supernatant equal volume of ethyl acetate was added in the ratio of 1:1 in a separating funnel, shaked well for $1 \mathrm{hr}$ and allowed to settle overnight in a stand. The upper aqueous layer containing the bioactive compound was collected in watch glass and kept in hot air oven at $40^{\circ} \mathrm{C}$ for 4 hours. Antibacterial activity of crude ethyl acetate extract against fish pathogens. The Bacterial strains were obtained from the Korean Culture Center of Microorganism $(\mathrm{KCCM})$, cultured in brain heart infusion broth (BHIB) at $37^{\circ} \mathrm{C}$ for $24 \mathrm{~h}$, and adjusted to $1.2 \times 10^{6} \mathrm{cfu} / \mathrm{ml}$ with sterile saline. The antibacterial activity of the crude ethyl acetate extract of isolated actinomycetes, was individually tested against five gram-negative (Edwardsiella tarda, Vibrio anguillarum, V. furnissii, V. fluvialis, V. ichthyoenteri) and two gram-positive (Streptococcus iniae, S. parauberis) fish pathogenic bacteria. Growth of the bacteria was measured at $540 \mathrm{~nm}$ using a UV spectrophotometer (Libra S22 UV/Visible, Biochrom, England).

Minimum inhibitory concentration. Sterilized filter paper discs (6-mm diameter) were soaked in $1 \mathrm{ml}$ crude ethyl acetate extract dissolved in dimethyl sulfoxide (DMSO) to a concentration of $100 \mu \mathrm{g} / \mathrm{ml}$, then serially diluted to six concentrations: $100,50,25,12.5,6.25$ and $3.12 \mu \mathrm{g} / \mathrm{ml}$. A sterile cotton swab was dipped into the standardized bacterial test suspensions and used to evenly inoculate the entire surface of brain heart infusion agar (BHIA) plates. The plates were allowed to dry for $5 \mathrm{~min}$ and the discs soaked with crude extracts were placed on them with sterile forceps. Blank paper discs with DMSO were used as the control. The inoculated plates were incubated at $35-37^{\circ} \mathrm{C}$ for $24 \mathrm{~h}$. Antibacterial activity was evaluated by measuring the distances of the inhibition zones of the tested bacteria, which were calculated as (diameter of inhibition zone - diameter of disc)/2 and expressed in $\mathrm{mm}$.

Free radical-scavenging ability. The free radical-scavenging ability of crude ethyl aceate extract of isolated actinomycetes was determined using a stable 2, 2-diphenyl2-picrylhydrazyl radical $\left(\mathrm{DPPH}^{15}\right)$. Free radical working solutions were prepared by dissolving $30 \mathrm{mg}$ DPPH in $100 \mathrm{ml}$ ethanol. An aliquot of $0.5 \mathrm{ml}$ of the sample was added to $3 \mathrm{ml}$ DPPH working solution. The mixture was vigorously shaken and left to stand in the dark for $24 \mathrm{~h}$ at room temperature, then the decrease in absorbance was measured at $517 \mathrm{~nm}$ versus a blank solution (ethanol). Results were compared with standard antioxidant ascorbic acid (ASA). Lower absorbance of the reaction mixture indicates higher free radical-scavenging activity. All determinations were performed in triplicate. The affinity of the test material to quench DPPH radicals (\% inhibition of DPPH) was calculated as \% Inh DPPH $=100(\mathrm{ADPPHC}-$ ADPPHS)/ADPPHC.

Beta-carotene bleaching assay. The antioxidant potential of crude ethyl acetate extract was measured by modifying the beta-carotene bleaching assay described by Suja et al. ${ }^{16}$. About $210 \mu \mathrm{l}$ of a solution of beta-carotene $(1 \mathrm{mg} / \mathrm{ml})$ in chloroform was placed in a round flask containing $5 \mu \mathrm{l}$ linoleic acid and $42 \mu \mathrm{l}$ Tween-20. The chloroform was removed in a rotary evaporator at $40^{\circ} \mathrm{C}$ and $10 \mathrm{ml}$ distilled water was added to form an emulsion with continuous shaking. Approximately $200 \mu \mathrm{l}$ of 
the emulsion was added to $50 \mu \mathrm{l}$ of five concentrations of the extract in a 96-well microplate. The emulsion without beta-carotene was used as a blank, BHT was used as a positive control, and wells containing the beta -carotene emulsion with DMSO instead of extract served to calculate the extent of bleaching. The plate was read at $450 \mathrm{~nm}$ immediately $(0 \mathrm{~h})$ and after $2 \mathrm{~h}$ of incubation at $50^{\circ} \mathrm{C}$ in the dark. Antioxidant activity (\%AA) was measured as 1 - 100(AS0 - AS2/AC0 -AC2) where $\mathrm{AS} 0$ and AS2 are absorbance with extracts at $0 \mathrm{~h}$ and $2 \mathrm{~h}$, respectively, and AC0 and $\mathrm{AC} 2$ are absorbance of the control at $0 \mathrm{~h}$ and $2 \mathrm{~h}$, respectively.

Cytotoxicity and antiviral activity. The fish cell line Epithelioma papulosum cyprinid $\left(\mathrm{EPC}^{17}\right)$ was used to test the toxic effect and antiviral activity of crude extract of isolated actinomycetes species on same cell batches in triplicate. About $1 \times 10^{6}$ cells were seeded into 96-well microplates in minimum essential medium (MEM) with $10 \%$ fetal bovine serum (FBS) and incubated at $23^{\circ} \mathrm{C}$. After $24 \mathrm{~h}$, the EPC monolayers were exposed to $20 \mu \mathrm{l}$ of seven doses $(1,2,5,10,20,50,100 \mu \mathrm{g} / \mathrm{ml})$ of crude extract, dissolved in DMSO to a final concentration that never exceeded $0.5 \%$ (v/v), for another hour. The media was replaced with fresh MEM containing 2\% FBS and incubated for an additional $24 \mathrm{~h}$ and the dose-dependent toxic effects of the extract were assessed with 3-(4,5-dimethylthiazol-2-yl)-2,5-diphenyltetrazolium bromide (MTT) and tryphan blue assays. Cells without crude extract served as the blank. The antiviral effects of the $S$. carpaticus crude extract were assessed by adding $20 \mu \mathrm{l}$ viral hemorrhagic septicemia (VHS) viral suspension to the 24-h EPC monolayers. After $1 \mathrm{~h}$, the monolayers were treated with the different concentrations of crude extract and incubated for another $1 \mathrm{~h}$. The media was replaced with fresh MEM with 2\% FBS and incubated for an additional $24 \mathrm{~h}$ to check viral proliferation using MTT assay. The effective concentration (EC50) and cytotoxic concentration (CC50) were determined by regression analysis of the dose-response curve and selectivity index (SI) was derived from the average results of the triplicates.

MTT assay. After one day of exposure the medium was aspirated aseptically and replaced with $100 \mu \mathrm{l}$ MTT, a yellow tetrazollium salt, dissolved in phosphate buffered saline (PBS) at a concentration of $5 \mathrm{mg} / \mathrm{ml}$. The culture plates were gently shaken and incubated for $4 \mathrm{~h}$. In solution, MTT is converted to a blue formazan crystal by mitochondrial succinate dehydrogenase of living cells. The crystals that formed within the cells were solubilized with $100 \mu \mathrm{l}$ DMSO and shaken well. Absorbance of the blue formazan chromophore was determined at $570 \mathrm{~nm}$ in an automated plate reader. Percentage cell viability (CV) was calculated as 100 (Average cell viability of treated cell (ACVs) - average cell viability of control cell $(\mathrm{ACVc})$.

Statistical analysis. All experiments were carried out in triplicate or quadruplicate and expressed as means \pm standard error. Statistical analyses were performed with SPSS version 16.0 (SPSS Chicago, IL, USA) using unpaired t-tests or one-way repeated measures ANOVA when appropriate. If significant by ANOVA, differences between means were determined using Duncan's multiple range tests $(p<0.05)$.

\section{RESULTS AND DISCUSSION}

Spore forming actinobacteria were isolated from seawater of Jeju Island, South Korea and identified as members of the genus Streptomyces carpaticus MK-01.The isolate MK-01 was Gram positive bacteria showing gray spores bearing dark brown mycelial colony with purple pigment. Scanning electron microscope observation showed the filamentous nature of bacterial cells (Fig. 1). Previous study have referred those dark-brown substances present in actinomycetes as melanin or melanoid pigments which are negatively charged composed of multi-functional 
polymers and polyphenolic compounds produced by fermentative oxidation, rich in radioproductive and antioxidant properties ${ }^{18}$. Other report on melanin pigments obtained from marine Streptomyces showed antibacterial activity ${ }^{19}$.

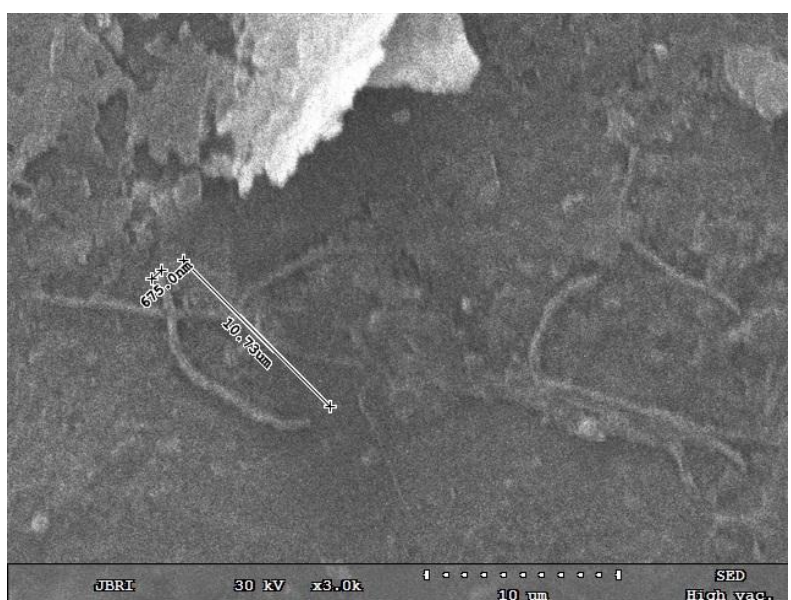

Fig.1. Scanning electron microscopic image of Streptomyces carpaticus - MK01 isolate.

For most actinomycetes, the optimum growth temperature is $23-37^{\circ} \mathrm{C}^{20}$ whereas Goodfellow and Williams ${ }^{21}$ reported that most of the actinomycetes behave as mesophiles with an optimum growth at $30^{\circ} \mathrm{C}$. Present study also found that the isolated $\mathrm{MK}-01$ grow at $\mathrm{pH}$ and temperatures ranged from 4 to 8 and 25 to $37^{\circ} \mathrm{C}$, respectively. Moreover, streptomycetes are known to prefer neutral to alkaline environmental $\mathrm{pH}$, the optimal growth $\mathrm{pH}$ range being 6.5 to $8.0^{22}$. However, acidophilic and alkalophilic streptomycetes have also been reported ${ }^{23}$.

Phylogenetic analysis confirmed that the isolated MK-01 as Streptomyces carpaticus MK-01 (Fig. 2). In this study, universal primers were used for amplification and sequencing the gene $16 \mathrm{~S}$ rDNA of the isolate MK-01. This result is in consistent with previous reports ${ }^{24,25}$ and it is necessity to consider both the genetic and phenotypic aspects in identifying the actinomycetes ${ }^{26}$. The isolate MK-01 shows a broad spectrum of antimicrobial activity against Gram positive ( $S$. iniae, $S$. parauberis) and Gram negative bacterial fish pathogens. Inhibition zones showed that DMSO had no antibacterial activity against any bacterial strain while $S$. carpaticus MK-01 crude ethyl acetate extract showed a significant range of antibacterial activity against gram-positive bacteria than Gram-negative bacteria $(\mathrm{P}<0.05)$ (Table 1). Previous studies have reported that bioactive substances produced by actinomycetes act on cell wall biosynthesis ${ }^{27,28}$.

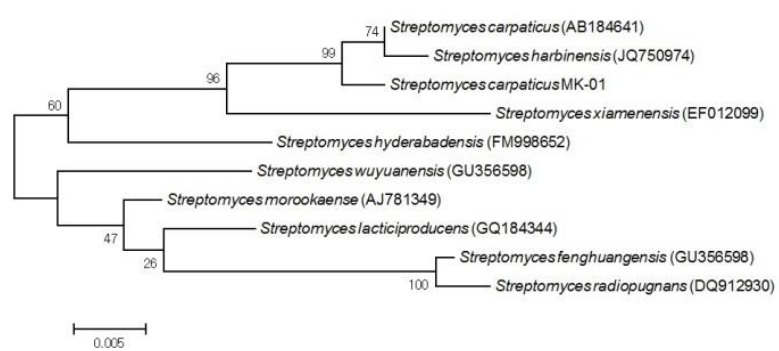

Fig.2. Phylogenetic tree based on 16S rRNA gene sequence analysis of Streptomyces carpaticus - MK01 isolate. 
Table 1. Zone of Inhibition ( $\mathrm{mm}$ ) of Streptomyces carpaticus MK-01 ethyl acetate extracts against seven fish pathogens.

\begin{tabular}{lllllll}
\hline & $3.12 \mu \mathrm{g} / \mathrm{ml}$ & $6.25 \mu \mathrm{g} / \mathrm{ml}$ & $12.5 \mu \mathrm{g} / \mathrm{ml}$ & $25 \mu \mathrm{g} / \mathrm{ml}$ & $50 \mu \mathrm{g} / \mathrm{ml}$ & $100 \mu \mathrm{g} / \mathrm{ml}$ \\
\hline Streptococcus iniae & $0.81 \pm 0.34^{\mathrm{a}}$ & $0.97 \pm 0.11^{\mathrm{ab}}$ & $1.32 \pm 0.12^{\mathrm{b}}$ & $3.13 \pm 0.18^{\mathrm{bc}}$ & $6.2 \pm 0.8^{\mathrm{bc}}$ & $8.1 \pm 0.04^{* * \mathrm{bc}}$ \\
Streptococcus parauberis $^{\mathrm{bc}}$ & $0.92 \pm 0.03^{\mathrm{a}}$ & $1.02 \pm 1.02^{\mathrm{ab}}$ & $1.39 \pm 0.11^{* \mathrm{~b}}$ & $3.5 \pm 0.24^{\mathrm{bc}}$ & $6.7 \pm 0.22^{\mathrm{c}}$ & $8.3 \pm 0.01^{* *} \mathrm{k}^{\mathrm{bc}}$ \\
Edwardsiella tarda $_{\text {Vibrio ichthyoenteri }}^{\mathrm{NS}}$ & $0.01 \pm 0.21^{\mathrm{NS}}$ & $0.13 \pm 1.02^{\mathrm{NS}}$ & $0.16 \pm 0.7^{\mathrm{NS}}$ & $0.26 \pm 0.03^{\mathrm{NS}}$ & $1.06 \pm 0.11^{\mathrm{NS}}$ & $1.3 \pm 0.04^{\mathrm{NS}}$ \\
Vibrio furnissii $_{\text {Vibrio harvi }}^{\mathrm{NS}}$ & $0.04 \pm 0.11^{\mathrm{NS}}$ & $0.09 \pm 0.02^{\mathrm{NS}}$ & $0.13 \pm 1.06^{\mathrm{NS}}$ & $0.76 \pm 0.14^{\mathrm{NS}}$ & $1.3 \pm 0.29^{\mathrm{NS}}$ & $1.5 \pm 0.21^{\mathrm{NS}}$ \\
Vibrio anguillarum $^{\mathrm{NS}}$ & $0.11 \pm 0.32^{\mathrm{NS}}$ & $0.03 \pm 1.1^{\mathrm{NS}}$ & $0.08 \pm 0.98^{\mathrm{NS}}$ & $0.36 \pm 0.2^{\mathrm{NS}}$ & $1.2 \pm 0.07^{\mathrm{NS}}$ & $1.37 \pm 0.18^{\mathrm{NS}}$ \\
\hline
\end{tabular}

All values are mean \pm SE; $n=3 ; * *$ Highly significant, *significant different between extract concentration; Bacteria sharing letters are not significantly different $(p>0.05)$.

In recent years much attention has been devoted to natural antioxidant and their association with health benefits ${ }^{29}$. DPPH radical scavenging ability was found to be decreased significantly while the beta-carotene bleaching activity increased with increasing concentration of $S$. carpaticus MK-01 crude extract than the control (Fig. $3 \mathrm{a} \& \mathrm{~b})$. The antioxidant activity of MK-01 crude ethyl acetate $(\mathrm{CC} 50=84.5 \mu \mathrm{g} / \mathrm{ml})$ was significantly higher than in the antioxidant standard, BHT $($ CC50 $=64.75$ $\mu \mathrm{g} / \mathrm{ml}$ ). Oxidative stress created by free radicals are scavenged by antioxidants through cellular mechanisms, namely, prevention of chain initiation, decomposition of peroxides, transition of metal ion catalysts, and hydrogen abstraction ${ }^{30}$. Betacarotene undergoes rapid discoloration due to the bleaching activity induced by linoleic acid in the absence of an antioxidant ${ }^{31}$.

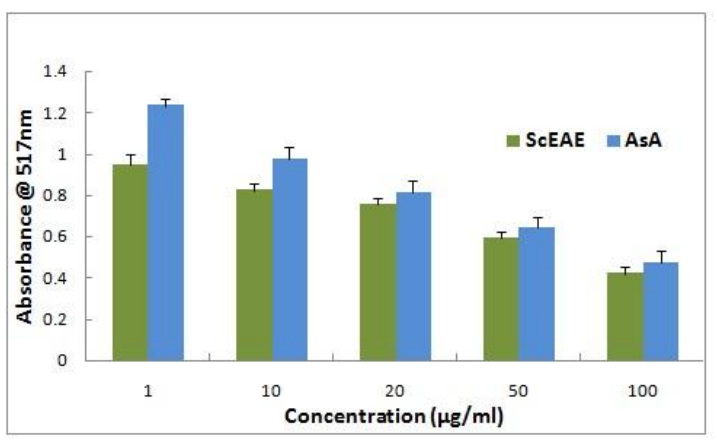

Fig.3a. Free radical scavenging activity of Streptomyces carpaticus ethyl acetate extract (ScEAE)

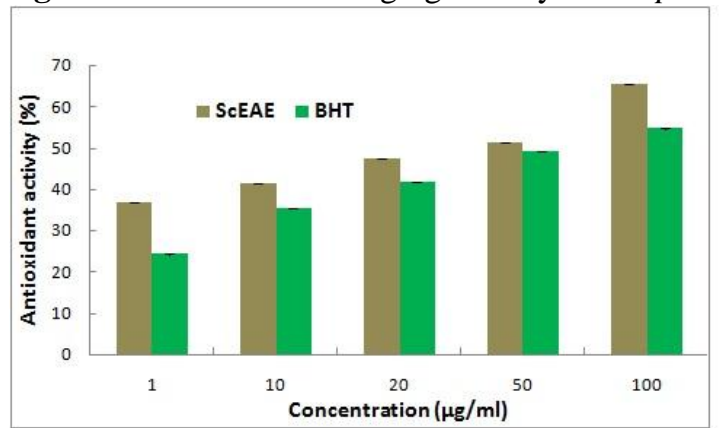

Fig. 3b. Beta-carotene bleaching ability of Streptomyces carpaticus ethyl acetate extract (ScEAE)

As the crude ethyl acetate extract of isolate MK-01 shown significant antioxidant potential, the extract was tested for its in vitro cytotoxicity and antiviral effect on the EPC cell line. The $S$. carpaticus MK-01 crude exract had a dose dependent cytotoxic effect on the EPC cell line with $C C_{50}$ as $53.71 \mu \mathrm{g} / \mathrm{ml}$ and VHS viral infected EPC with $E C_{50}$ as $8.72 \mu \mathrm{g} / \mathrm{ml}$ (Fig. 4). The toxic effect increased from $5 \mu \mathrm{g} / \mathrm{ml}$ concentration of the extract. With the obtained selectivity index (6.15), $C C_{50}$ and $E C_{50}$ of the crude ethyl acetate extract of MK-01 isolate against the VHS virus- 
infected EPC cell line signifies its antiviral effects, as similar to the antiviral effect of marine- derived Streptomyces sp. against H1N1 influenza A virus ${ }^{32}$.

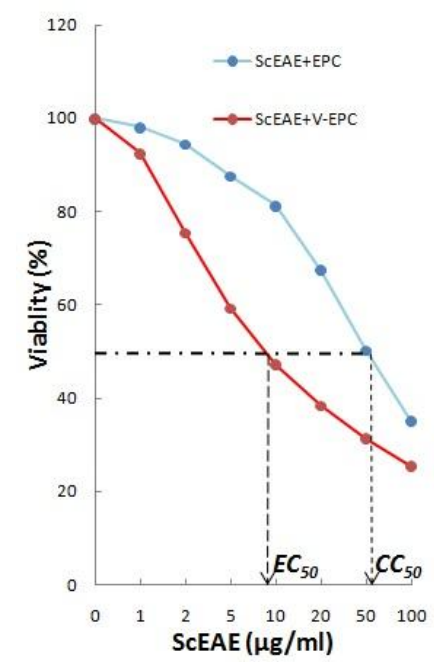

Figure 4. MTT assay - normal (EPC) and viral infected (V-EPC) cells treated with Streptomyces carpaticus ethyl acetate extract (ScEAE). EC50 is effective concentration and IC50 is cytotoxic concentration (at 50\% viability of EPC).

Hence, the isolate $S$. carpaticus- MK-01 from Jeju Island seawater contains antimicrobial compounds which could be used as potential source of antibiotics against fish pathogens. Further, studies are needed to assess its role as a probiotic organism as previous studies have reported the efficacy of Streptomyces as a potential probiotic source in aquaculture ${ }^{33,34}$. Thus the isolate MK-01 and its ethyl acetate extract containing secondary metabolites could be potential used in the aquatic feed formulation as a natural antibiotic which may reduce the risk of side effects and lower the cost of fish feeding in the aquatic food industries.

\section{CONCLUSIONS}

Taken together our study concludes that $S$. carpaticus-MK01 strain from Jeju Island contains antioxidant and antimicrobial compounds which could be potentially used for the aquaculture industries.

\section{ACKNOWLEDGEMENTS}

The authors are grateful to the National Research Foundation of Korea (NRF) grants funded by the Leading Human Resource Training Program of Regional Neo industry through the Ministry of Science, ICT and Future planning (2016H1D5A1911152).

\section{REFERENCES}

1- Subasinghe RP. Epidemiologic al approach to aquatic animal health management: opportunities and challenges for developing countries to increase aquatic production through aquaculture. Prev. Vet. Med. 2005;67:117-24.

2- Ganguly S, Paul I, Mukhopadhayay SK. Application and effectiveness of immunostimulants, probiotics, and prebiotics in aquaculture: a review. Isr. J. Aquacult. Bamidgeh, 2010;62(3):130-8. 
3- Bondad-Reantaso MG, Subasinghe RP, Arthur JR, Ogawa K, Chinabut S, Adlard R, Tan $\mathrm{Z}$ and Shariff M. Disease and health management in Asian aquaculture. Vet. Parasitol. 2005;132:249-72.

4- Abutbul S, Golan-Goldhirsh A, Barazani O, Ofir R, Zilberg D. Screening of desert plants for use against bacterial pathogens in fish. Isr. J. Aquacult. Bamidgeh, 2005;57:71-80.

5- Singh SB and Barrett JF. Empirical antibacterial drug discovery-foundation in natural products. Biochem. Pharmacol. 2006;71:1006-15.

6- Walsh CT. Antibiotics: actions, origin, resistance.ASM Press, Washington, DC. (2003)

7- Adinarayana G, Venkatesan M, Saisha V, Bapiraju VVSNK, Sujatha P, Premkumar J et al. Resistoflavine, cytotoxic compound from a marine actinomycete, Streptomyces chibaensis AUBN 1/7. Microbiol. Res. 2007;162:322-7.

8- Imada C, Koseki N, Kamata M, Kobayashi T, Hamada-Sato N. Isolation and characterization of antibacterial substances produced by marine actinomycetes in the presence of seawater. Actinomycetologica, 2007;21:27-31.

9- Vimal V, Rajan BM, Kannabiran K. Antimicrobial activity of marine actinomycete, Nocardiopsis sp. VITSVK 5 (FJ973467). Asian J. Med. Sci. 2009;1:57-63.

10- Ramesh S, Rajesh M, Mathivanan N. Characterization of a thermostable alkaline protease produced by marine Streptomyces fungicidicus MML1614. Bioprocess Biosyst. Eng. 2009;32(6):791-800.

11- Manivasagan P, Venkatesan J, Sivakumar K, Se-Kwon Kim. Pharmaceutically active secondary metabolites of marine actinobacteria. Microbiological Research. 2014;169:262-78.

12- Thakur D, Yadav A, Gogoi BK, Bora TC. Isolation and screening of Streptomyces in soil of protected forest areas from the states of Assam and Tripura, India, for antimicrobial metabolites. J. Mycol. Med. 2007;17:242-9.

13- Shirling EB and Gottlieb D. Methods for characterization of Streptomyces species. Int. J. Sys. Bacteriol. 1966;16:313-40.

14- Weisberg WG, Barns SM, Pelletier DA, Lane DJ. 16S ribosomal DNA amplification for phylogenetic study. J. Bacteriol. 1991;173:679-703.

15- Von Gadow A, Joubert E, Hansmann CF. Comparison of antioxidant activity of aspalathin with that of other plant phenols of Rooibosd tea (Aspalathon linearis), atocopherol, BHT, and BHA. J. Agr. Food Chem. 1997;45:632-638.

16- Suja KP, Jayalekshmy A Arumughan C. Antioxidant activity of sesame cake extract. Food Chem. 2005;91:213-219.

17- Fijan N, Sulimanovic D, Bearzoi M, Muzinic D, Zwillenberg LO, Chilmonczyk S, Vautherot JF, deKinkelin P. Some properties of the Epithelioma papulosum cyprini (EPC) cell-line from carp, Cyprinus carpio. Annales de Virologie.1983;134:207-22.

18- Dastager S, Li WJ, Dayanand A, Tang SK, Tian XP, Zhi XY, Xu LH Jiang CL. Separation, identification and analysis of pigment (melanin) production in Streptomyces. Afr. J. Biotechnol. 2006;5:1131-34.

19- Vasanthabharathi V, Lakshminarayanan R, Jayalakshmi S. Melanin production from marine Streptomyces. Afr. J. Biotechnol. 2011;10:11224-34.

20- Stal LJ, Moezelaar R. Fermentiaon in cyanobacteria. FEMS Microbiol. Rev. 1997;21:179-211.

21- Goodfellow M, Williams ST. Ecology of actinomycetes. Ann. Rev. Microbiol. 1983;37:189-215.

22- Locci R. Streptomycetes and related genera. Bergey's Manual of Systematic Bacteriology, Williams and Wilkins Company, Baltimore:1989;4:2451-508.

23- Kontro M, Lignell U, Hirvonen MR, Nevalainen A. pH effects on 10 Streptomyces spp. growth and sporulation depend on nutrients. Lett. Appl. Microbiol. 2005;41:32-8.

24- Jeffrey LSH. Isolation, characterization and identification of actinomycetes from agriculture soils at Semongok, Sarawak. Afr. J. Biotechnol. 2008;7:3697-702.

25- Arasu MV, Duraipandiyan V, Agastian P Ignacimuthu S. Antimicrobial activity of Streptomyces spp. ERI-26 recovered from Western Ghats of Tamil Nadu. J. Med. Mycol. 2008;18:147-53.

26- Goodfellow M, Jones AL, Maldonado LA, Salanitro J. Rhodococcus aetherivorans sp. nov., a new species that contains methyl-t-butyl ether degrading actinomycetes. Syst. Appl. Microbiol. 2004;27:61-5. 
Marine actinomycetes against fish pathogens

27- Schneider T, Gries K, Josten M, Wiedemann I, Pelzer S, Labischinski H, Sahl HG. The lipopeptide antibiotic Friulimicin B inhibits cell wall biosynthesis through complex formation with bactoprenol phosphate. Antimicrob. Agents Chemother. 2009;53(4):16108 .

28- Singh MP, Petersen PJ, Weiss WJ, Janso JE, Luckman SW, Lenoy EB, Bradford PA, Testa RT, Greenstein M. Mannopeptimycins, new cyclic glycopeptide antibiotics produced by Streptomyces hygroscopicus 1l-ac98: antibacterial and mechanistic activities. Antimicrob. Agents Chemother. 2003;47(1):62-9.

29- Ali MA, Keera AA, Helmy MS, Abd El-Nasser HN, Ahmed KA ElHennawi HM. Selection of Pigment (Melanin) production in Streptomyces and their application in Printing and Dyeing of Wool Fabrics. Res. J. Chem. Sci. 2011;1(5):22-8.

30- Yildirim A, Mavi A, Oktay M, Kara AA, Algur OF, Bilaloglu V. Comparison of antioxidant and antimicrobial activities of tilia (Tilia argentea Desf ex DC), sage (Salvia triloba L.), and black tea (Camellia sinensis) extracts. J. Agr. Food Chem. 2000;48:50304.

31- Sharififar F, Dehghan-nudeh GH, Mirtajaldini M. Major flavonoids with antioxidant activity from Teucrium polium L. Food Chem. 2009;112:885-8.

32- Wang P, Xi LJ, Liu PP, Wang Y, Wang W, Huang Y, Zhu WM. Diketopiperazine derivatives from the marine-derived actinomycete Streptomyces sp. FXJ7.328. Mar. Drugs. 2013;11:1035-49.

33- Das S, Lyla PS, Ajmal Khan S. Application of Streptomyces as a probiotic in the Laboratory Culture of Penaeus monodon (Fabricius). Isr. J. Aquacult. Bamidgeh, 2006;58:198-204.

34- Tan LTH, Chan KG, Lee LH, Goh BH . Streptomyces bacteria as potential probiotics in aquaculture. Front. Microbiol.2016;7:79. 